UDK 78:81'373.46

Prethodno priopćenje

Rukopis primljen 14. VII. 2018.

Prihvaćen za tisak 11. XI. 2018.

\title{
Delphine-Anne Rousseau
}

Centre de Recherche en Terminologie et Traduction (CRTT)

Université Lumière Lyon 2

rdelphineanne@yahoo.fr

\section{EARLY MUSIC AND TERMINOLOGICAL RESURGENCE: A DIACHRONIC STUDY OF FRENCH AND ENGLISH MUSIC TERMINOLOGY FROM THE SECOND HALF OF THE $17^{\mathrm{TH}}$ CENTURY}

Research on historical terminology is a key step to understanding a specialised language and its evolution, and to getting to the core of a historical discipline in context. This type of research is particularly of interest in fields like Early music, especially as early-music specialists have to use and master the proper terminology for the music they specialise in and that is very often different from the terminology traditionally used in music, and as they have to be able to communicate efficiently with specialists from other fields. In this paper, the author will present an ongoing doctoral research project on the music terminology in use in France and in England during the second half of the $17^{\text {th }}$ century and its evolution through time, the methodology being used and some methodological issues, as well as present a few examples illustrating the author's work.

\section{Introduction}

Just as is the case for natural languages and cultures, and for most specialised languages, the language of music (and we're not talking about musical language here, but really about the language used to talk about and write on music) is alive and well. It has, evidently, evolved alongside music itself. Thus, the music terminology that was in use during the second half of the $17^{\text {th }}$ century and that was proper to the music of that period has evolved in its own way (not unlike other music terminologies belonging to other periods, of course). It lived, declined, disappeared in part, and some of its terms have come back to life, mostly due 
to the early-music movement. As the recent movement towards authenticity and historicity in music (both in performance and understanding of music) prompted scholars and musicians to approach writings on music with fresh eyes, they were faced from the start with terminological issues: how can one apprehend and fully grasp terms that are still in use, but that seem to convey a different meaning in period texts? How can one reach an accurate understanding of musical terms that have long fallen out of use (can it even be done?)? How can one be certain that one's understanding of those terms matches that of other colleagues? And how should one understand and translate ancient musical terms into other languages? Most of the research carried out so far in the understanding of earlymusic terminology is the fruit of work accomplished by musicians and music scholars. Although some consensus seems to have been reached within the field of early music, it can probably be refined, and substantial work remains to be done: are we certain the terms we use, as early-music performers, are the correct ones? There are different schools in the early-music field and, even at the time, authors did not always agree on music terminology. Also, how can one be certain that the correct meaning of these terms is conveyed to one's readers and interlocutors?

As a baroque violinist also trained in musicology and a terminologist, I decided to undertake a diachronic terminological study, and try and see how terminological tools and methods could help to expand and fine-tune our knowledge of French and English music terminology from the second half of the $17^{\text {th }}$ century. This research focuses on three different points:

1. drawing a portrait of late $17^{\text {th }}$-century music terminology in France and in England;

2. establishing language-to-language equivalences;

3. based on a terminological sample, studying how music terminology has evolved through time between then and now, paying particular attention to the phenomenon of terminological resurgence (i.e. terms and/or concepts that had gone out of use and that have regained widespread currency in contemporary practice of early music).

Yet, how should such diachronic terminological research be carried out? How does working from a terminological point of view make this research any diffe- 
rent from research that has been done on this topic? How can one adapt different terminological approaches and methods in order to make them fit one's purpose? What terminological tools can or cannot be used? What corpora should be used and how should they be built? What should be done with the results of this terminological survey? And, finally, how best to advise users of this terminology in various communication contexts? An analysis of a selection of representative examples drawn from this research will aim to illustrate the methodology that has been used and provide some answers to these questions.

\section{A word on diachrony}

Before going on with the description of this research, one has to be clear about what is to be meant by diachrony. What is usually taught in terminology is that studying recent or current-day terminology consists in a synchronic study, whereas studying terminology from the past or the evolution of terminology consists in a diachronic study. However, when one comes to think of it, studying terminology from the past actually amounts to studying a given terminology in a remote moment in the past, therefore, in other words, studying what was then current-day terminology - which means studying a synchrony from the past, what one could call a remote synchrony. And, going further along this line, the evolution of terminology, diachronic terminology, could be considered as nothing but the study of a succession of small synchronies that overlap with each other, as shows in the following figure:

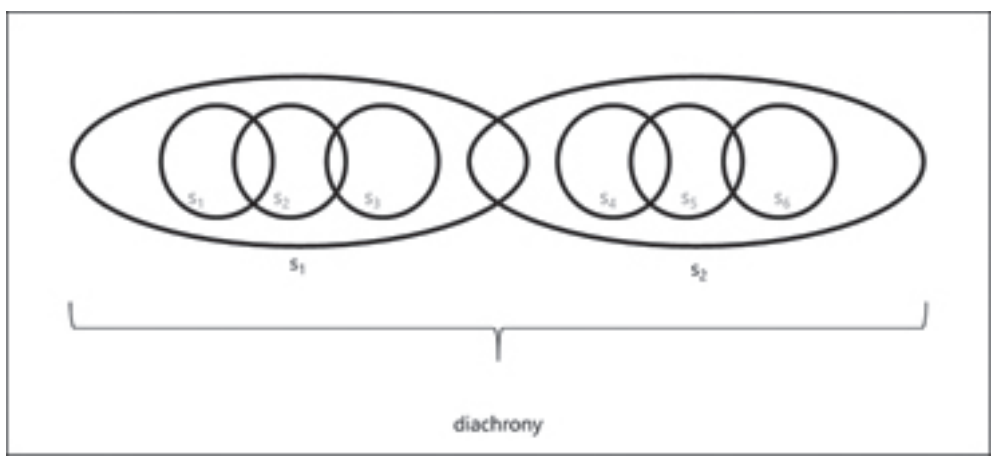

Figure 1. Synchronies (s) and diachrony 
So, to answer the first issue raised above, how should such diachronic terminological research be carried out? Well, given what we have just seen, it should consist in drawing successive synchronic portraits of a given terminology, at different moments in time, taking a step back and, finally, seeing what has happened (or not) through time.

The second issue to tackle was, how does working from a terminological point of view make this research any different from research that has been carried out so far on this topic? As mentioned above, research in historical terminology in music has been done mostly - if not only - by musicologists. Now, as proficient in the field as they are, they are not necessarily familiar with the study of terms (terminology work) or with the terminological methodologies that allow a thorough study of a given terminology. On the other hand, terminologists, as enthusiastic as they may be about music, do not necessarily have all the musical and musicological knowledge that guarantee a perfect understanding of music terminology.

The early-music dictionaries that have been consulted previous to this research were, for the most part, published by musicologists. They are certainly of great interest and they do give a good idea of the meaning conveyed by this terminology, but some questions remain after consulting them: are the definitions a compendium of all the definitions found by the author, or do they correspond to what the author believes the defined concepts mean? Some dictionaries do not even provide references for their definitions - although there generally is a reference list for the whole dictionary. An exception to this, though, is the phenomenal work done by Graham Strahle (1995). First of all, Strahle, in his introduction, gives an enlightening explanation of his work and of the peculiarities of earlymusic terminology. And the format of the dictionary is also different: Strahle doesn't write a definition for each term but presents all the definitions he has found of all concepts in primary sources, whether they be musical sources or lexicographical sources.

Coming back to this second issue, it appears that using the methodologies developed for terminology, combined with a thorough knowledge of the field of Early music is what is required in order to draw an accurate portrait of this terminology and to see how it matches or differs from the one now in use. 
Before going on with providing answers to the questions raised in the introduction, let us see how this research has been conducted for the past few years.

\section{Users of early-music terminology}

The first issue that arises when embarking on this research journey is this: who uses early-music terminology? The obvious and automatic answer to this question would be, of course: early-music performers and musicologists. If this were the case, the interest of this terminological work would be there, but this research may not be so relevant. Since identifying the users of a given terminology and the users of one's given terminology product is one of the key steps in the elaboration of any terminology project, this was given some proper thought at the very beginning of this research project. Who was this research directed at? And the more one thought about this, the more categories of users of early-music terminology one found.

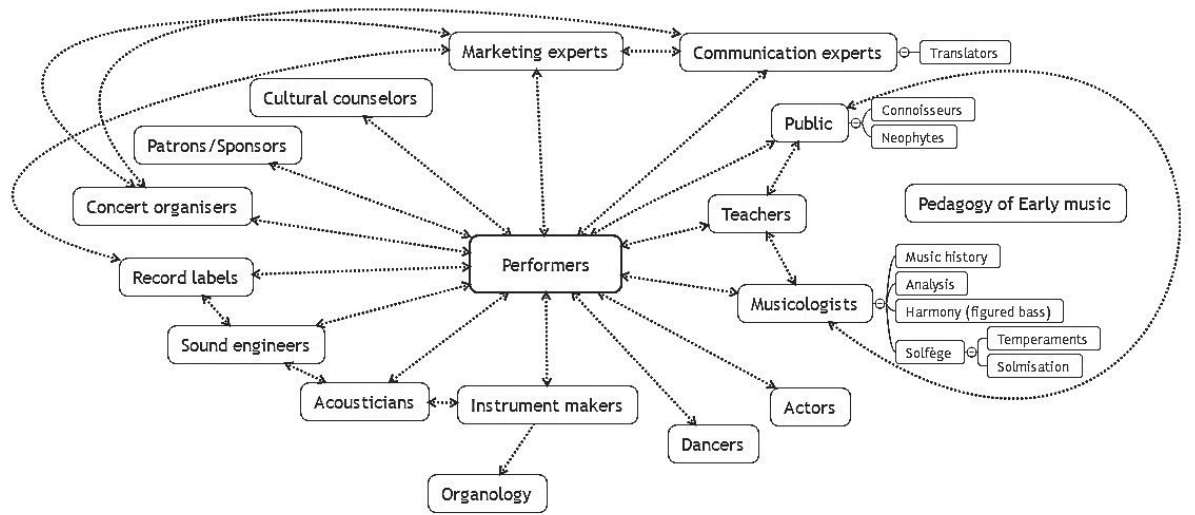

Figure 2. Categories of early-music terminology users

As you can see in this diagram, the number of potential users of early-music terminology is rather surprising. They do not, obviously, all require the same level of terminological proficiency, but they are all likely to need at least, in some contexts, a certain understanding of this terminology, as appears in the following matrix. 


\begin{tabular}{|c|c|c|c|c|c|}
\hline Users & $\begin{array}{l}\text { Specialised } \\
\text { scientific } \\
\text { discourse }\end{array}$ & $\begin{array}{l}\text { Official } \\
\text { scientific } \\
\text { discourse }\end{array}$ & $\begin{array}{c}\text { Pedagogical } \\
\text { scientific } \\
\text { discourse }\end{array}$ & $\begin{array}{c}\text { Semi- } \\
\text { polularisation }\end{array}$ & Popularisation \\
\hline Performers & $\bullet$ & 0 & $\bullet$ & - & - \\
\hline Teachers & - & - & - & - & - \\
\hline $\begin{array}{l}\text { Musicologists/Music } \\
\text { historians }\end{array}$ & 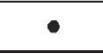 & & - & - & - \\
\hline Patrons and sponsors & & $\theta$ & $\theta$ & $\odot$ & - \\
\hline Music producers & $\odot$ & & & - & $\bullet$ \\
\hline $\begin{array}{l}\text { Public } \\
\text { (connoisseurs/neophytes) }\end{array}$ & & & & $\bullet$ & - \\
\hline Concert organisers & 0 & $\boldsymbol{\theta}$ & $\boldsymbol{Q}$ & 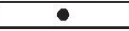 & - \\
\hline Acousticians & $\odot$ & $\theta$ & $\theta$ & - & 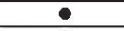 \\
\hline Instrument makers & 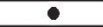 & $\theta$ & $(\bullet)$ & 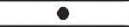 & 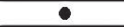 \\
\hline Staff of record labels & $\odot$ & $\theta$ & $\theta$ & $\bullet$ & $\bullet$ \\
\hline $\begin{array}{l}\text { Sound engineers and } \\
\text { teehnicians }\end{array}$ & & $\theta$ & $\theta$ & o & $\bullet$ \\
\hline Communication experts & $\odot$ & $\theta$ & $\theta$ & 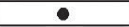 & 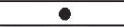 \\
\hline Translators & $\odot / \bullet$ & $\mathrm{O} / \bullet$ & $\mathrm{O} / \bullet$ & $\mathrm{O} / \bullet$ & $\mathrm{O} / \bullet$ \\
\hline Marketing experts & ○ & $\theta$ & $\theta$ & & $\bullet$ \\
\hline $\begin{array}{l}\text { Cultural counselors and } \\
\text { attaches }\end{array}$ & & $\bullet$ & & - & - \\
\hline
\end{tabular}

Figure 3. Matrix of the discourse categories and levels of proficiency required to be mastered by the different categories of users of early-music terminology

In any case, all the different users may find themselves in situations in which they have to interact and communicate efficiently with each other, and this only goes to show the relevance of this research project.

\section{Methodology}

The second big issue that arose was: how best to proceed in order to accomplish this challenging task? The general purpose was clear, but a methodological frame was required to carry out this work. Looking at the different approaches used in terminology, it soon appeared that the best option would be to come up with a custommade methodology based on a compendium of different terminological approaches: mainly the cultural and socioterminological approaches. What was certain was that this research was going to be based on a corpus-based term extraction.

What does one mean by corpus terminology? Well, quite the same as one does by corpus linguistics: it consists in a description of the actual use of terminology as occurs in texts. What this means is that one cannot rely merely on the content of a specialised dictionary or on mere definitions in order to understand a given terminology and to understand how and in what contexts it is used. The study of texts, in terminology, has become more and more an important part of 
terminology work. This study may be based on written or oral texts - thus being not so different in a way than a field study in ethnomusicology, for instance. In this case, the general guidelines on corpus-based approaches were followed. Four different corpora were called for: a term-extraction corpus for French period texts, a term-extraction corpus for English period texts, a French reference corpus (with texts dating from the late $17^{\text {th }}$ century until now) and, finally, an English reference corpus (with texts dating from the late $17^{\text {th }}$ century until now). The rigour with which one performs terminological work is the guarantee of its scientific value, and it must show at every step of the way, whether it be when building a corpus, establishing a protocol for term extraction, collecting and recording data, or, finally, when interpreting and analysing the data.

Before selecting the texts to be used - in other words, before starting to build the four corpora - it was necessary to decide which data should be retrieved and which data were relevant. The retained data categories were the following:

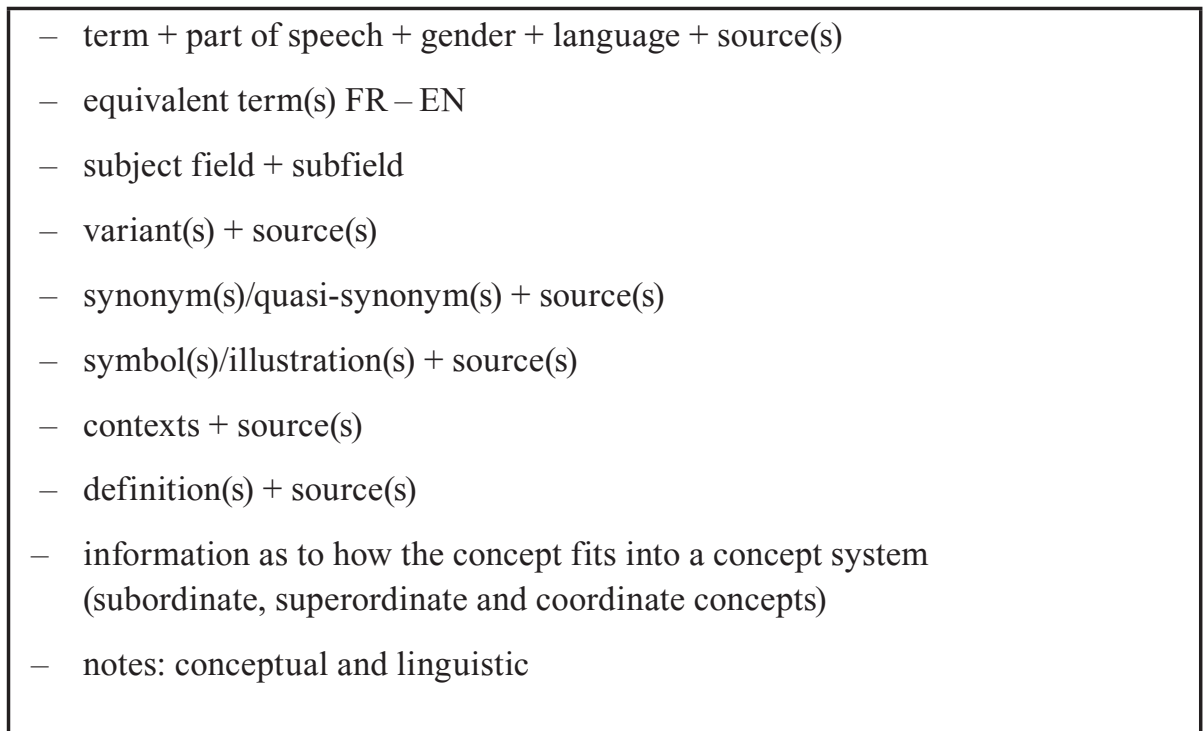

Figure 4. Categories of data to be retrieved

Each data item encountered in the corpora will be registered into the database, and only once the data processing is completed will some items be put aside if considered superfluous or repetitive. Although any definition suggested by an author will be entered in the definition field during data retrieval, the final definition will be 
written at the end of the data processing, so as to make sure it encompasses all the conceptual information collected from the corpora and that it seems to agree with all the proposals from the authors. Language-to-language equivalences will also be established at the end of the data processing, on the basis of a comparison of all the conceptual information retrieved for the records in both languages, and will only be confirmed if an exact or nearly exact match is found between both records.

When talking about music terminology, what springs to mind is terms. But, as in general terminology, one often forgets that terminology is fundamentally about concepts, and that terms are, above all, the designations of concepts. Doing so, one tends to disregard a large share of material: non-textual elements. And, when one thinks of non-textual elements, one automatically thinks of symbols and illustrations. And, of course, in what concerns sources from the second half of the $17^{\text {th }}$ century, this is correct: the only non-textual information that is at one's disposal is pictorial. But what about musical notation: aren't some examples in music musical explanations of concepts? The figure below shows examples of such musical explanations by Chambonnières (1670) and d'Anglebert (1689) of non-textual contexts related to the different graces. Hence the importance of being able to include multimedia files in the database.
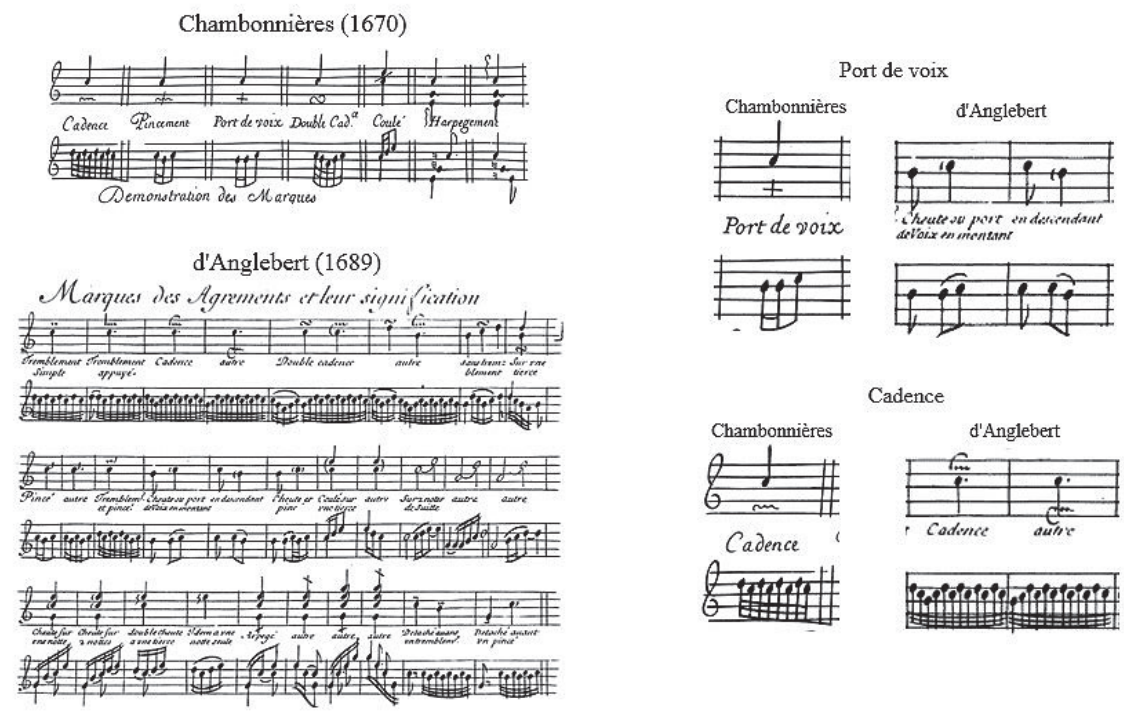

Figure 5. Examples of non-textual information, Chambonnières and d'Anglebert 
If one were to work on today's early-music terminology, one could also think of using recordings of performed musical examples as explanations of the corresponding musical concepts.

Now, the idea of building a huge collection of period writings on music in order to study music terminology is one thing, but then what texts should be included in the corpora? What types of period texts are there? What types are available, and what types are relevant?

Methods and treatises are undoubtedly the first category of texts to be considered. These works, written for honnetes hommes and honnetes femmes (men and women of culture), music enthusiasts - but not necessarily meant for the education of future professional musicians - were a means to spread musical knowledge and know-how. It is therefore in the treatises that one is most likely to find the most complete terminology. Given their didactic nature, these texts introduce basic concepts, name them and define them more or less formally. They also suggest concept systems that help to classify and hierarchize them.

Other writings on music or musical texts are prefaces which appear at the beginning of music books. It was of course very common at the time for composers to include a presentation of their work, in which they would provide players and singers with meticulous directions as to how the music included in the book was to be performed - an explanation for the notation used or for graces, amongst other things. Some forewords - for instance Purcell's preface to his 1683 Sonnatas' in III Parts shown below - also include explanations for new musical terms used in the book. In this text, Purcell explains the "few terms of Art unusual to [the reader]" (foreign words) Adagio and Grave, Presto Largo, Poco Largo, Largo, Allegro, Vivace and Piano that he uses in his Sonatas'. However short, these prefaces must be considered when building a corpus. 


\section{To the Reader.} Ingenuous Reader,

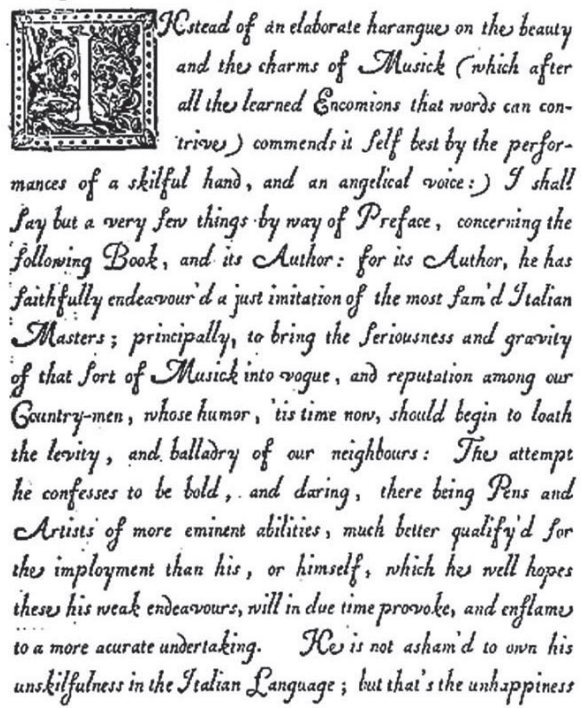

of his Education, which cainnot justly to accourted his fault, hovever he thinks he may warrantably affirm, that he is not mistaken in the pover of the Italian Kotes, or elegancy of their Gompositions, which the would recommend to the Englisk Artists. There has been neither care, nor industry wanting, as well in contriving, as revising the whole Nork; which had been abroad in the world much $\rho_{0 o n e r}$, but that he has now thought fit to cause the whole Thorough $\mathcal{B}_{\text {ass }}$ to be Engraven, which was a thing quite besides his first Resolutions. It remains only that the English $\mathcal{P}_{\text {ractitioner be enformid, that }}$ he will find a fen terms of Clt perhaps unusual to him; the chief of which are these following: Adagio and Grave, which impore nothing but a very slonv movement : Prefto Largo, Poco Largo, or Largo by it Self, a middle movement : Allegro,

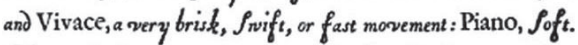
The Cluthor has no more to add, tut his hearty wishes, that his Book may fall into no other hands but theirs who carry Musical Souls about them; for he is willing to flatter himself into a belief, that with Such his labours will Seem neither unpleasant, nor unprofitable. $\quad \mathrm{Vale}$.

Figure 6. Purcell's Foreword to his 1683 Sonnatas' in III Parts

Lexicographical works - dictionaries - could also have been interesting candidates for the corpora. Two examples of such works that could have been included in the French corpus are Furetière's Dictionnaire universel from 1690, and Sébastien de Brossard's Dictionnaire de musique, first published in 1703. However, as specialised as they may get, dictionaries do not necessarily reflect natural discourse: they belong to metalinguistic speech, and the definitions they contain are not always written by experts of the field (in Furetière's case, for example), and they certainly would not suffice as a basis for drawing the portrait of music terminology at the time. This is why it was decided to use these works as a reference instead of including them directly into the corpora meant for term extraction - or using them as a direct reference for ultimate definitions of the studied concepts.

Other types of period writings on music include letters, journals, accounts of journeys, memoirs and even ledger books. Although all of these often contain interesting - if not relevant-information on music, music making and music writing, and could have been regarded as a fortunate addition to these corpora, it would have proved difficult to choose which of the great many writings of this 
type to include. One could almost consider that these writings could actually constitute a corpus by themselves.

The most difficult thing when gathering a corpus for term extraction is knowing where to stop. The more one digs, the more potential elements one finds. This is why it is important to establish some criteria for picking texts and to decide when to close the corpora. Otherwise, this becomes a never-ending project. One thing that definitely tells one where to stop is the availability of sources. When gathering a corpus of writings on music from the second half of the $17^{\text {th }}$ century, one is completely dependent on what writings are actually available. Some original copies of treatises can be found in libraries across the world. A wide variety of treatises are also available in reprints as facsimiles. But fortunately, more and more of these writings are emerging on the Internet, on a number of websites (the Center for the History of Music Theory and Literature at Indiana University, Bassus generalis, Early English Books Online, Google Books, IMSLP and Early Music Sources are just a few examples for English sources). However, some problems arise when extracting terms from these sources, as will be explained later. The two corpora built for this term extraction include about sixty texts, mostly music treatises and forewords of music books. These are open corpora, so that any additional text fitting the established criteria will be added to the corpora.

Corpus terminology nowadays comes with a great ally: automatic term extraction (ATE) or automatic term recognition. Term extractors allow term extraction to represent an even smaller share of terminology work. And they do yield good results with modern texts: electronic documents or scans of printed documents. With ancient texts, however, it becomes impossible to use such tools, and this, for different reasons.

If one's corpus includes printed facsimiles, one automatically has to extract terms the old-fashioned way, i.e. manually. The same applies when using digital copies of ancient treatises. Some of the websites mentioned earlier-Google Books and Early English Books Online, for instance - have used OCR (optical character recognition) in order to provide plain-text versions of the books. This is a good start. However, while OCR generally works very well with modern typography, it often produces wretched results with ancient texts (due in part to a less regular typography and in part to some degradation of the original copy) as can be seen below: 


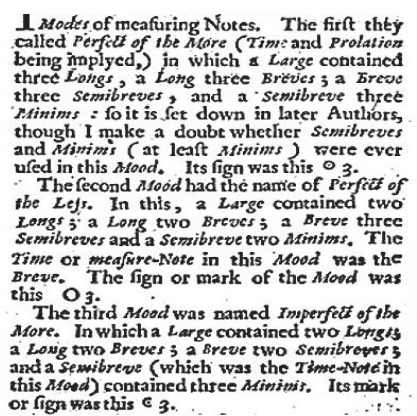

The first they called Perfect of the More (Tim: and Prolalion being rmplycd,) in which â Large contained three iftigs, a Long three Breves 5 a Breve three Semibreves, and a Sen/ibreve three Minims :so it is set down in later Authors, though I make a doubt whether Semibreves and Minims ( at least Minims) were ever used in this Mood, Its sign was this 03

The second Mood had the name of Perfe'Sf of the Leji. In this, a Large contained two $L<w g s 5$ a Long two Breves 5 a Breve three Semibreves and a Semibreve two Minims, The

Time Time or meaJnre-Nete in this Mood was the Breve. The sign or mark of the Mood was this $\mathrm{O} 3$.

The third Mood was named Imperfeff of the More. In which a Large contained two Lopg $\$ \$$ a Long two Breves -, a tfrez/e two Semi breve s 5 and a Semibre, ve (which was the Time^Notéih this Moed) contained three Minims. Its mark or sign was this G 3...;

Figure 7. Facsimile from Simpson's Compendium (1667: 14-15) and its OCR by Google Books

Another thing that vouches against using an automatic term extractor with ancient texts is the existence of innumerable spelling variants in these texts. While some of them are predictable, others consist in mere idiosyncrasies of the authors, and so it proves difficult not to miss out on some important terminological information when using an automatic tool. The Center for the History of Music Theory and Literature has gone one step further than OCR, offering a complete retranscription in plain text format of a great collection of treatises (both French and English). This has been extremely useful, although the website was unfortunately shut down for over a year.

However, in the end, and especially because of the importance of non-textual elements mentioned above (and, as shown in the examples, some of them include textual information - terms, mostly - that is not taken into account as such by OCR or by transcriptions to plain text format), it soon became clear that the manual approach would unfortunately have to be resorted to in all cases. This has been time-consuming work, but it is also a guarantee of the thoroughness of the terminological extraction process. Also, manual term (and context) extraction reduces noise significantly and offers hope for exhaustive term extraction.

Although the terms (together with all the conceptual and definitional information) are collected manually, an electronic tool is, however, being used when collecting data into the database. The choice was made early on to use an already-existing database system specialised for the collection and treatment of terminological data: i-Term, a terminological database system created by DanTerm, which offers many interesting features, one of them being the possibility to attach multimedia files to each terminological record. 


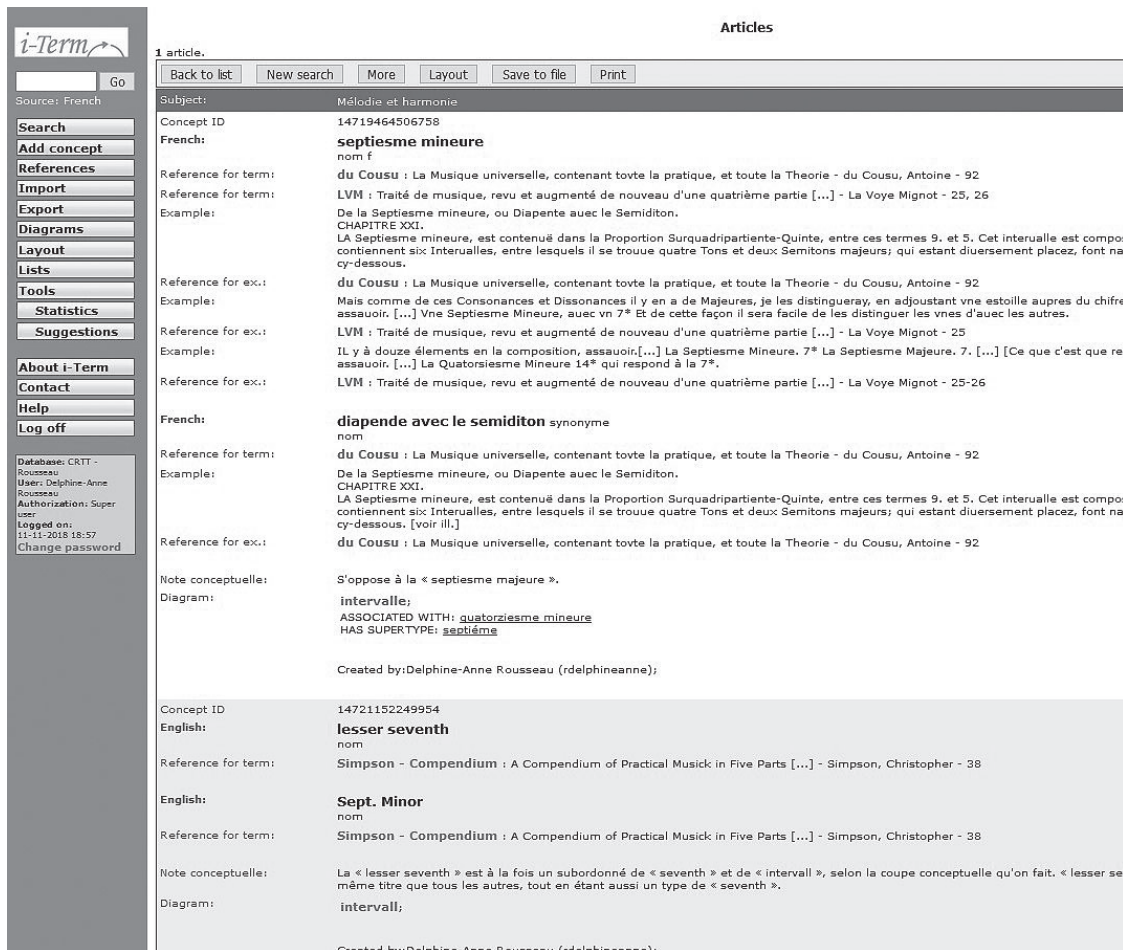

Figure 8. Screenshot from the i-Term database - septiesme mineure

\section{A few examples}

Over one thousand records have been created so far in the database and, of course, the scope of this paper is too limited to give a substantial share of examples. However, in order to shed light on some of the results this research has yielded, here are some cases of interest.

\subsection{Note values}

A first interesting case is that of note values. First of all, because this is a classic example of a concept system: many of the authors introduce them with the help of a tree diagram, showing that each note value is worth half of the note value corresponding to its superordinate concept, etc., as one can see below: 


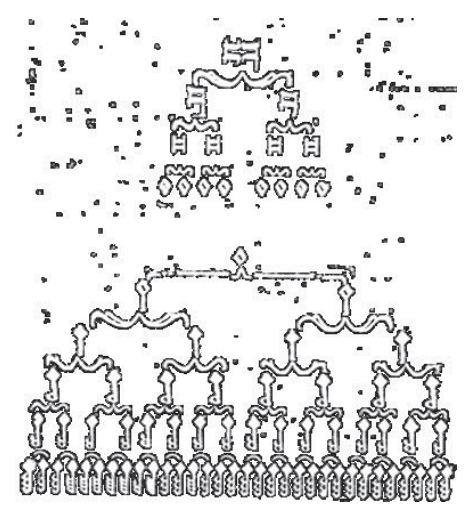

Figure 9. Tree diagram of note values in Simpson's Compendium (1667: 16)

However, there is more to this example. As has been explained, this project studies music terminology from the past and its evolution. But what one comes across in this case is that, in fact, many of the authors whose treatises are studied did the same. Indeed, many of the treatises included in the corpora not only introduce the note values in use at the time, but also introduce those used in the past, used by the Ancient, not in use anymore and so on. For example, Antoine $\mathrm{du}$ Cousu introduces eight note values: "There are eight note values in Music [...] and they are the Maxime [larga, Maxima nota], the Longue, the Brefve [Brief], the Semibrefve [semibrief], the Minime, the Semiminime, the Fuze [quaver], and the Semifuze [semiquaver], of which the last three were added so as to sing faster, because the Ancients used only the first five" (1658: 39). ${ }^{1}$

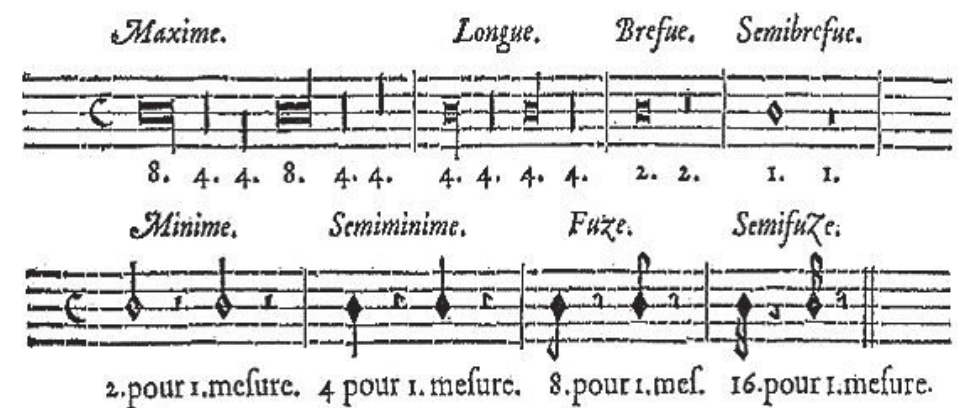

Figure 10. Note values in du Cousu (1658: 39)

Translation by the author. 
In his 1696 Elements de musique, Loulié wrote the same thing: "the Maxime, the Longue ou quarrée à queue and the quarrée" are found "in the music books of the Ancients or of foreigners" (1696: 30). ${ }^{2}$ However, by 1702, according to Michel de Saint-Lambert (1702: 25), these five note values seem to have completely disappeared, as he introduces only five note values: ronde, blanche, noire, croche, double-croche.

On the English side of the corpora, Christopher Simpson says:

"The first two Notes in use, were Nota Longa \& Nota Brevis, (our Long and Breve) in order to a long and short syllable. Only they doubled or trebled their Longa, and called it Larga or Maxima Nota, which is our Large. When Musick grew to more perfection, they added two Notes more, under the names of semi brevis and Minima Nota; (our semibreve and Minim) which later was then their shortest Note. To these, later times have added Note upon Note, till at last we are come to Demisemiquaver; which is the shortest or swiftest Note that we have now in practice" (1667: 13).

In this quote, one sees that Long, Breve and Large are older values than Semibreves and Minims, which are in turn older than Crotchet, Quaver, Semiquaver and Demisemiquaver. What is also interesting in Simpson's quote here, is that it implies that the characteristic shortest note was first attached to Minima Nota and, later, to Demisemiquaver, thus showing a very clear diachronic conceptual evolution. A third reason why this example is of interest lies in the fact that many - if not most - of the terms and concepts used by the authors for note values in use at the time and of the terms and concepts in use before their time, many of which had gone out of use or current use between 1700 and modern times in French (maxime, longue, quarrée, brève, semibrève, minime or semiminime), have nowadays regained current use amongst early-music performers, thus representing a case of terminological resurgence.

idem. 


\begin{tabular}{|c|c|c|c|c|c|}
\hline \multirow{2}{*}{$\begin{array}{l}\text { French } \\
\text { term(s) }\end{array}$} & \multicolumn{4}{|c|}{ Symbols used by } & \multirow{2}{*}{$\begin{array}{l}\text { English } \\
\operatorname{term}(\mathrm{s})\end{array}$} \\
\hline & $\begin{array}{c}\text { du Cousu } \\
\text { (1658) }\end{array}$ & $\begin{array}{l}\text { Loulié } \\
\text { (1696) }\end{array}$ & Playford (1674) & Simpson (1667) & \\
\hline maxime & $\frac{\text { Maxime. }}{8.4 .4 .8 .4 .4 .}$ & s. Rondes. & 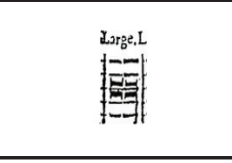 & Enge & $\begin{array}{c}\text { largel } \\
\text { largal } \\
\text { maxima } \\
\text { nota }\end{array}$ \\
\hline $\begin{array}{l}\text { longuel } \\
\text { quarrée } \\
\text { à queuë }\end{array}$ & 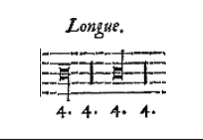 & 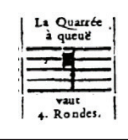 & $\begin{array}{l}\text { Long. } \\
\text { 㧝 }\end{array}$ & Lens. & long \\
\hline $\begin{array}{c}\text { quarréel } \\
\text { brefve }\end{array}$ & $\frac{\text { Brefue. }}{\frac{2.2 .}{2.6-I}}$ & $\left|\frac{\mid{ }^{\text {Lo Quarte }}}{\mid}\right|$ & Breves & 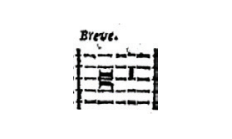 & breve \\
\hline $\begin{array}{l}\text { semib- } \\
\text { refvel } \\
\text { rondel } \\
\text { entiere }\end{array}$ & $\begin{array}{l}\text { Semibrefuc. } \\
\qquad \begin{array}{l}\text { I. } \\
\mathrm{x} .\end{array}\end{array}$ & 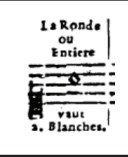 & Semibreve: & $\begin{array}{l}\text { Semibreva. } \\
\text { : }\end{array}$ & $\begin{array}{l}\text { semib- } \\
\text { reve }\end{array}$ \\
\hline $\begin{array}{l}\text { minimel } \\
\text { blanche } \\
\text { demie }\end{array}$ & 2.pour r.mefurc. & 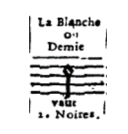 & Minim. & 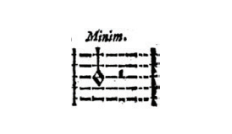 & minim \\
\hline $\begin{array}{l}\text { semimin- } \\
\text { imel } \\
\text { noirel } \\
\text { quart }\end{array}$ & Semiminime. & : & 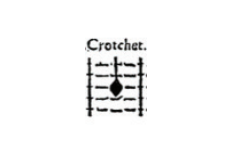 & $\begin{array}{l}\text { croches. } \\
\text { fyts: }\end{array}$ & $\begin{array}{c}\text { crotch- } \\
\text { et/cro- } \\
\text { chet }\end{array}$ \\
\hline $\begin{array}{c}\text { crochel } \\
\text { fuzel } \\
\text { huitiéme }\end{array}$ & 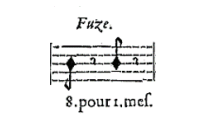 & $\mid \begin{array}{c}\text { Le Croche } \\
\text { Huiditme } \\
\text { Huates }\end{array}$ & 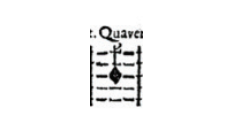 & 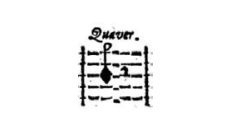 & quaver \\
\hline $\begin{array}{c}\text { double } \\
\text { crochel } \\
\text { semifuzel } \\
\text { seiziéme }\end{array}$ & $\frac{\text { Semifuze: }}{16 . \text { pour r.mefure. }}$ & 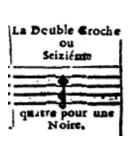 & 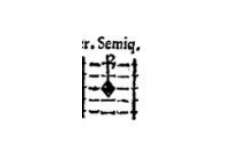 & 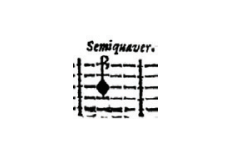 & $\begin{array}{l}\text { semi- } \\
\text { quaver }\end{array}$ \\
\hline
\end{tabular}

Figure 11. Comparative table of terms and symbols used by four authors for note values

\subsection{Chronometre and Sonometre}

Another interesting example drawn from my research can be found in Loulié's Elements. Indeed, it was in his 1696 treatise that he shared with the world one of his own inventions, the Chronometre. ${ }^{3}$ Loulié found that musical notation was

\footnotetext{
3 The Chronometre was approved by the Académie Royale des Sciences in 1701.
} 
Figure 12.

Loulié (1696)

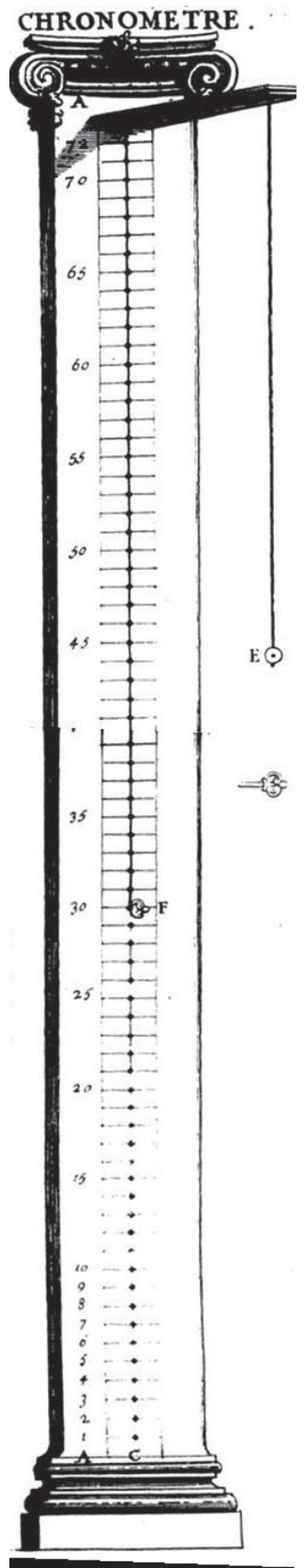

not sufficient to indicate how fast or how slow a piece was meant to be played, even when accompanied by some tempo indication, and found this was particularly the case with foreign music. He wished to be able to tell what duration in time a beat should have or, how many beats there should be per minute, and so he designed a machine "to measure Time". He therefore created this machine (Figure 10), and he explains thoroughly in his treatise how it works and how it is made, and provides the reader with precise instructions on how to build one. This example is of interest from various points of view. First, simply because the detailed description of his invention made by Loulié is a wealth of conceptual information-mostly about partitive concept systems. Second, because it tells or reminds one that such a device - in which one obviously recognises the ancestor of the metronome, which was to appear much later-had already been designed in the late $17^{\text {th }}$ century, and the literature tells us that this invention aroused interest and bore some relevance, as Diderot and Rousseau were to comment on it a few decades later. Finally, this example consists in an interesting case of diachronic terminological evolution. The concept of a machine measuring time would remain - hence the invention of the metronome, patented in 1801, but the concept of the Chronometre as designed by Loulié would disappear. However, the term chronometre was to be used again to designate a different concept widely known and used nowadays.

The same was to happen with another of Loulié's inventions. Working with mathematician Joseph Sauveur, he became concerned with tuning systems in general and with the tuning of harpsichords in particular. He therefore designed another device that he named Sonometre, a onestringed instrument designed to help tuning harpsichords, 
which was presented to the Académie Royale des Sciences and patented in 1699, and which he introduces and explains in his Nouveau Système de Musique in 1698. In this case, the concept of this device would reappear in the form of a tuner, and the term sonometre would be reused to designate another apparatus used by acousticians.

\section{Conclusion}

The purpose of this paper was to give an overview of my research, to explain briefly some of its methodological aspects, and to offer a glimpse at some cases of interest. These are only a few examples out of hundreds contained in my database. This research is still going on and should be completed within the next couple of years. By the end of this project, I hope to be able to provide as complete a database as is possible of French and English music terminology from the second half of the $17^{\text {th }}$ century, together with advice on the correct use of this terminology according to different communication contexts. Another purpose of this work is to make a methodological contribution on how to approach similar complex historical terminological works, not only in music, but in all subject fields linked with the Arts and Humanities. Finally, I hope to make a substantial contribution on the diachronic approach in terminological work in general, a special field of investigation that has yet to gain the full regard it deserves, despite its great contribution to the understanding of specialised languages and specialised fields.

\section{References:}

Brossard, SéBastien De. 1703. Dictionnaire de musique, contenant une explication des termes grecs, latins, italiens et françois les plus usitez dans la musique. Christophe Ballard. Paris.

D’Anglebert, Jean-Henri. 1689. Pièces de Clavecin avec la maniere de les Jouer - Livre Premier. Paris.

Chambonnières, Jaques-Champion De. 1670. Les pieces de clavessin: premier livre. Jollain. Paris.

Du Cousu, Antorne. 1658. La Musique universelle. Paris.

Furetière, Antoine. 1690. Dictionnaire universel: contenant généralement tous les mots françois tant vieux que modernes, et les termes de toutes les sciences et des arts [...]. Chez Arnout \& Reinier Leers. The Hague. 
Loulié, Étienne. 1696. Éléments ou principes de musique [...]. Christophe Ballard. Paris. Loulié, ÉTIENNE. 1698. Nouveau Système de Musique ou Nouvelle division du monocorde dans laquelle on donne les raisons de tous les intervalles de musique par rapport à l'accord du clavecin ordinaire. Christophe Ballard. Paris.

Playford, John. 1674. An introduction to the skill of musick [...]. London.

Purcell, Henry. 1683. Sonnata's of III parts: two viollins and basse to the organ or harpsecord. J. Playford and J. Carr, for the author. London.

Saint-Lambert, Michel. 1702. Principes du clavecin.

Simpson, Christopher. 1667. A Compendium of Practical Musick. London.

Simpson, CHRISTOPHER. 1667. A Compendium of Practial Musick [OCR text version]. London. Online version available at https://books.google.fr/books?id=UUNDAAAAcAAJ\&pg= PA15\&focus $=$ viewport $\& \mathrm{dq}=$ christopher + simpson + compendium $\&$ hl $=$ fr\&output $=$ text \#c_top.

Strahle, Graham. 1995. An early music dictionary: musical terms from British sources, 1500-1740. Cambridge University Press. Cambridge; New York.

\section{Rana glazba i terminološka obnova: \\ Dijakronijsko istraživanje francuskoga i engleskoga glazbenog nazivlja iz druge polovice 17. stoljeća}

\section{Sažetak}

Istraživanja u području povijesne terminologije ključan su korak u razumijevanju strukovnoga jezika i njegove evolucije te razumijevanje same srži povijesne discipline u kontekstu. Takva je vrsta istraživanja osobito zanimljiva u područjima kao što je rana barokna glazba, posebice stoga što stručnjaci za ranu glazbu moraju svladati odgovarajuće nazivlje i primjenjivati ga u glazbi koju su specijalizirali, a to je nazivlje često veoma drukčije od nazivlja tradicionalno upotrebljavanoga u glazbi. Također moraju biti u mogućnosti i učinkovito komunicirati sa stručnjacima iz drugih područja. U ovom se radu predstavlja tekuće istraživanje u okviru doktorske disertacije glazbenoga nazivlja koje se upotrebljavalo u Francuskoj i Engleskoj tijekom druge polovice 17. stoljeća te njegov razvoj tijekom vremena. Iznosi se i primijenjena metodologija s određenim metodološkim pitanjima kao i nekoliko primjera koji ilustriraju autoričin rad.

Keywords: diachrony, music terminology, terminological work, 17th century, France, England, Early music

Ključne riječi: dijakronija, glazbeno nazivlje, terminološki rad, 17. stoljeće, Francuska, Engleska, rana barokna glazba 


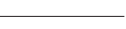

